\title{
Total Petroleum Hydrocarbons Contamination of the Surface Water and Sediments of Orashi River, Engenni, Ahoada West, Rivers State, Nigeria
}

\author{
Edori, E. $\mathbf{S}^{1}$ \\ Edori, O. $\mathbf{S}^{2 \rtimes(D)}$ \\ Bekee, $\mathrm{D}^{\mathrm{s}}$
}

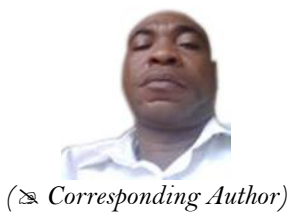

${ }^{1,2}$ Department of Chemistry, Ignatius Ajuru University of Education Rumuolumeni, Port Harcourt, Rivers State, Nigeria.

Email:onisogen.edori@yahoo.com

${ }^{s}$ Department of Chemistry, Rivers State University, Port Harcourt, Rivers State, Nigeria.

\section{Abstract}

The level of contamination of Orashi River by total petroleum hydrocarbons were investigated through the collection of surface water samples and sediment samples from four locations along the river. Determination of the level of contamination was done with the use of gas chromatography-flame ionization detector after following laid down clean-up procedures. The results obtained showed that total petroleum hydrocarbons in the surface water were $10.913 \pm 2.2022 \mathrm{mg} / \mathrm{L}, \quad 7.645 \pm 2.683 \mathrm{mg} / \mathrm{L}, \quad 9.074 \pm 2.1654 \mathrm{mg} / \mathrm{L}$ and $12.212 \pm 3.3034 \mathrm{mg} / \mathrm{L}$ for stations 1, 2, 3 and 4 respectively with a mean value of $9.961 \pm 2.5885 \mathrm{mg} / \mathrm{L}$, while in the sediment samples concentration values recorded were $22.3925 \pm 5.2104 \mathrm{mg} / \mathrm{Kg}, 35.1071 \pm 9.9652 \mathrm{mg} / \mathrm{Kg}$, $50.4431 \pm 15.9916 \mathrm{mg} / \mathrm{Kg}$ and $29.3869 \pm 8.0410 \mathrm{mg} / \mathrm{Kg}$ for stations 1,23 and 4 respectively with a mean value of $34.3324 \pm 9.8021 \mathrm{mg} / \mathrm{Kg}$. The partition coefficient calculations revealed that the sediment phase is more stable for total petroleum hydrocarbons as compared to the water phase. The analysis of the randomly collected samples revealed that total petroleum hydrocarbons have contaminated the river and therefore adequate steps should be taken to remedy the present condition of the Orashi River in order to mitigate any probable rise in the quantity of total petroleum hydrocarbons in the river above allowable limit.

Keywords: Contamination, Gas chromatography-flame ionization detector, Orashi River, Sediments, Surface water, Total petroleum hydrocarbons.

Citation | Edori, E. S; Edori, O. S; Bekee, D (2021). Total Petroleum Hydrocarbons Contamination of the Surface Water and Sediments of Orashi River, Engenni, Ahoada West, Rivers State, Nigeria. Asian Review of Environmental and Earth Sciences, 8(1): 68-76.

History:

Received: 6 October 2021

Revised: 29 October 2021

Accepted: 22 November 2021

Published: 13 December 202

Licensed: This work is licensed under a Creative Commons

Attribution 3.0 License (c) E E

Publisher: Asian Online Journal Publishing Group
Acknowledgement: All authors contributed to the conception and design of the study.

Funding: This study received no specific financial support.

Competing Interests: The authors declare that they have no conflict of interests.

Transparency: The authors confirm that the manuscript is an honest, Transparency: The authors confirm that the manuscript is an honest,
accurate, and transparent account of the study was reported; that no vital features of the study have been omitted; and that any discrepancies from the study as planned have been explained.

Ethical: This study follows all ethical practices during writing.

\section{Contents}

1. Introduction

2. Materials and Methods

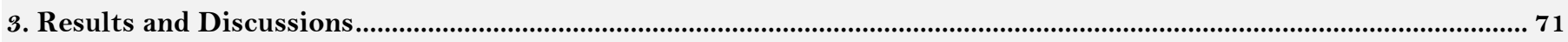

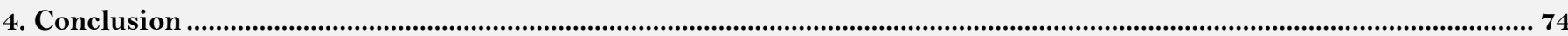

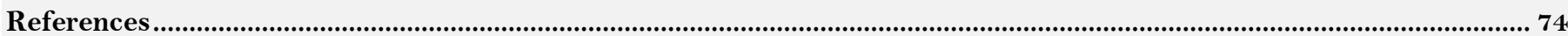




\section{Contribution of this paper to the literature}

This study contributes to existing literature by unveiling the concentrations of total petroleum hydrocarbons in water and sediment matrixes of the Orashi River in Engenni, Rivers State. The study further confirmed that the sediment is a repository or sink of pollutants in aquatic medium by holding more of total petroleum hydrocarbon components than the surface water.

\section{Introduction}

The quality of water is very important in the life of aquatic organisms. The quality of water has been under great attack due to oil exploration and exploitation in the Niger Delta Region of Nigeria. Poor water quality and pollution arose as a result of the rise in industrial and agricultural activities, population growth and urbanization [1]. Organisms or certain species may be eliminated at certain level of pollution due to their inability to withstand stress [2]. Water bodies need special attention to prevent and protect it from excessive devastation and degradation that resulted from industrial, agricultural and other forms of environmental deterioration [3, 4].

Water as an essential aspect of human life is obtained from natural sources such as ground water (well and borehole), also known as geological water and water bodies such as lakes, streams, rivers, lagoons, seas and oceans (also known as surface water) [5-7]. Even though water is very essential and of immense benefits, there is difficulty in its accessibility due to its high rate of degradation from contamination and pollution. As a result of anthropogenic activities, technological advancement, increased human population, industrialization, oil production activities, etc, a wide range of contaminants are introduced daily into the water bodies and the aquatic environment, which have contributed negatively to the poor water qualities of rivers of Niger Delta [8-10].

A major challenge in the area designated as Niger Delta in Nigeria, is the issue of water quality. The contamination, degradation and pollution of water in this region is as a result of the increase in the production of petroleum hydrocarbons [11-13]. This has contributed greatly to the environment being degraded and polluted [14]. Due to the activities of man, such as the drive for the use of crude oil-based products like diesel, petrol (gasoline), lube oil, asphalt, etc, the contamination of the water body has greatly increased. Petroleum hydrocarbons find its way into the rivers through marine transportation, aerial depositions from gas flaring, runoffs from polluted land due to rain, dumping directly into the river, refinery effluents, industrial and municipal waste [15-17]. The increased activities of oil exploitation and exploration by multinationals, illegal refining of oil and bunkering, transportation and storage of petroleum products has caused unquantifiable pollution along the creeks, rivers, estuaries and other coastline in the Niger Delta area. This has led to the depletion of the sources of livelihood of the people of the region $[18,19]$.

Despite the huge resources that petroleum hydrocarbons have contributed to the globe, its contamination due to the exploration and production operations has caused widespread environmental pollution, poor human health, socio-economic challenges and even conflicts among host communities and even nations [20]. The discharge of crude oil (petroleum hydrocarbons) has caused or contributed greatly to severe environmental pollution, bringing about environmental degradation and deterioration, loosing of cultural heritage and also creating socio-economic problems over the past years in the Niger Delta region of Nigeria [21-24].

The contamination and deterioration of the river causes some serious consequences on the ecosystem, which result in adverse effect on the marine ecosystem by impacting on wild life, fishing, tourism, transportation and other associated businesses within that area [25, 26]. Crude oil or petroleum hydrocarbons may find its way into the environment through oil spill, which may occur due to equipment failure, damage of pipeline through willful act, operational mistakes or errors, sabotage, corrosion of pipes and storage tanks [27, 28].

Environmental reports have shown that high level of organic (including petroleum hydrocarbons) and inorganic chemicals have impacted on the environment, due to the activities of these industries. Their effects have been adverse and have exceeded both international and national acceptable limits in different environments [2932]. The activities of petroleum industries have severe environmental impacts and consequences on the inhabitants or the particular environment where the activity took place. As a result of oil prospecting activities, there is great possibility of environmental degradation which may arise as a result of oil spill [33].

As a result of the toxic nature of crude oil and its products, there is widespread destruction of farmland in addition to other socio-economic consequences to the host communities of the trans national oil companies. When there is oil spill at sea due to illegal oil bunkering activities, pipeline explosion, the effect is as dangerous and drastic as on the land, posing a threat to the sea organisms [33-35]. Aquatic organisms which survive through oxygen metabolism may die due to oil film blocking the oxygen being dissolved in the water. The process of oil spill also renders the water quality low and unfit for drinking, tourism, agriculture and other related activities [36, 37].

Health deterioration of man and other organisms is also another effect of total hydrocarbon content. It poses serious health threat due to gases associated with it. Total hydrocarbon content can affect the central nervous system, lungs and blood cells of man and animals. Other effects are asphyxiation of water organisms, which comes as a result of oil coating the water surface. This may result in death of water organisms, causing impairment in growth and development of marine organisms, mutagenic and carcinogenic effects are produced in man. There is also the problem of marketability of marine fishes, crustaceans, molluscs and other sea animals due to objectionable flavour which reduces their acceptability. Total petroleum hydrocarbons may also lead to death of both water flora (plants) and fauna (animals), [19, 38-40].

Due to oil prospecting and exploitation activities, pollutants such as petroleum hydrocarbons which are toxic and persistent in the environment are always discharged [41]. There is also great absence of portable water due to these activities, which has resulted in the unfitness of most river water for consumption and thus a threat to aquatic life, which man depends on for food. This has led to the search for alternative sources of water for both domestic and industrial uses, which also are not altogether safe from hydrocarbons and other pollutants [42]. Studies have shown that aquatic organism accumulate hydrocarbons in their tissues at varying degrees [43], which at very high concentrations can both be risk to them and their consumers. 
The research work determined the extent of contamination/pollution resulting from total petroleum hydrocarbons in surface water and sediments of the Orashi River. The concentration of the total petroleum hydrocarbons was determined using chromatographic methods with the equipment model Agilent 5890 gas chromatograph - flame ionization detector (GC- FID).

\section{Materials and Methods}

\subsection{Study Area and Location}

The study area covers the Orashi River in Engenni, Ahoada West Local Government Area of Rivers State, in the Niger Delta area of South South Nigeria. The Orashi River is a tributary of River Niger and runs from Imo State through Ogba Egbema Ndoni Local Government Area to Engenni in Ahoada West Local Government Area of Rivers State. The sample location points in the Engenni axis of the Orashi River were within the geographic positions $4^{\circ} 107.3^{\prime} \mathrm{N}, 6^{\circ} 30^{\prime} 6.6^{\prime \prime} \mathrm{E}$ and $4^{\circ} 59^{\prime} 10.1^{\prime \prime} \mathrm{N}, 6^{\circ} 27^{\prime} 2.5^{\prime \prime} \mathrm{E}$. The inhabitants of Engenni are mainly fishermen and farmers. There are numbers of activities that take place within the Engenni Axis of the river which includes, oil exploration and production, illegal oil bunkering, transportation, etc. Oil production facilities that belongs to multinational oil companies includes flow station, oil fields, gas plants, which has constantly led to the contamination of the river. The environmental impact and pollution due to oil exploitation and production over the years in this region have been a source of worry for the inhabitants. Other activities that are predominant in the river apart from oil production includes fishing, sand mining recreational activities (such as swimming and canoeing).

\subsection{Collection of Water Sample}

Water sample was collected from four different stations in Orashi River using glass bottles. The glass bottles were previously washed with dichloromethare to ensure no contamination with the water sample. Three different points were collected in each station at a depth of $40 \mathrm{~cm}$ and mixed together to form a representative sample. Preservation of the water sample was done by adding $2 \mathrm{ml}$ of $0.2 \mathrm{~m} \mathrm{H}_{2} \mathrm{SO}_{4}$ to bring the $\mathrm{pH}$ to about 2 . In other to prevent any harm or contamination, the bottles are covered with sterile pieces of aluminum foil, after which the bottles were tightly covered with plastic screw. The bottles were then kept in an ice packed cooler to keep it at $4^{\circ} \mathrm{C}$ then transported to the laboratory for sample pre-treatment and analysis [44].

\subsection{Collection of Sediment Sample}

Sediment samples were collected at the four different stations in Orashi River from the top few centimeters deep. Bulk representative samples were formed by mixing three points sediments together. The samples were collected using a hand held, van veen grab and transferred to glass bottles then transported to the laboratory. The collected sediment samples are treated as in the case of water samples.

\subsection{Water Samples Extraction for Total Petroleum Hydrocarbon Determination}

Water samples were filtered and then subjected to extraction procedures through the use of separatory funnel. Water samples of different volume were collected from different stations, and extracted into a two liters' (2L) glass separatory funnel and filtered with a glass stopper $30 \mathrm{ml}$ dichloromethane as solvent for extraction. The separatory funnel was shaken for at least 5 minutes. This allows the organic layer to clearly separate itself from the aqueous layer. $5 \mathrm{~g}$ of anhydrous sodium sulphate was mixed with the extract (lower layer) in order to remove water. The sample was then collected into a beaker with the aid of filter paper. The filtrate is allowed to evaporate at room temperature in a fume cupboard. The filtrate was allowed to be concentrated to $3 \mathrm{ml}$. the process of extraction was repeated three times for each sample collected [45].

\subsection{Extraction of Sediment Sample for Total Petroleum Hydrocarbon Determination}

An analytical weighing balance was used to weigh $10 \mathrm{~g}$ of sediment sample and was transferred into an amber bottle. Then $5 \mathrm{~g}$ of anhydrous sodium sulphate $\left(\mathrm{Na}_{2} \mathrm{SO}_{4}\right)$ was measured and put into the amber glass bottle that contains the sediment sample, and then the sediment sample is shaken vigorously for effective mixing of particles. The purpose of adding anhydrous sodium sulphate is to reduce moisture from the sediment sample. After through mixing of the sample, $30 \mathrm{ml}$ dichloromethane was added to the sediment sample as the extracting solvent. After the addition of dichloromethane, the amber bottle was then very tightly closed and then transferred to a mechanical shaker and was agitated at room temperature and the sample allowed to settle for $1 \mathrm{hr}$ interval. Then using a $110 \mathrm{~mm}$ filter paper the sediment sample was filtered into a clean beaker that has board, the filtrate of the sediment sample was allowed to concentrate to $1 \mathrm{ml}$ by evaporation [45].

\subsection{Sample Clean Up}

Column preparation was performed through the introduction of glass-wool into an already washed chromatographic column. Then into an already clean beaker silica gel was introduced. Addition slurry was made into chromatographic column. An Anhydrous sodium sulphate was added into the column then the addition of pentane thereafter. In a previously cleaned beaker, the concentrated sample was mixed with cyclohexane and then introduced into the column already prepared. The sample was eluted with pentane and then collected into the beaker below the column. Furthermore, the elution of sample was carried out by the introduction of more pentane, after which the column was then rinsed with dichloromethane. The sample was allowed to stand in a fume cupboard after elution at room temperature for evaporation to take place [45].

\subsection{Sample Separation and Detection}

Agilent $5890 \mathrm{~N}$ gas chromatography-flame ionization detector (GC-FID) was used for the detection of total petroleum hydrocarbons in sediment and water samples at the different stations of the area under study [46]. 3ml of concentrated sample was injected into the gas chromatography vial for cleaning of syringe, the blank dichloromethane was injected into micro-syringe of gas chromatography. Before the analysis of the sample, the 
cleaning of the syringe was done thrice. The micro-syringe was rinsed later with the sample after which the sample was then injected into the gas chromatography for the total separation of the different components of the sample. After separation of components in the sample, the amount of total petroleum hydrocarbon content resolved at a particular chromatogram was then measured in $\mathrm{mg} / \mathrm{Kg}$ for the sediment sample and $\mathrm{ml} / \mathrm{L}$ for water sample.

\subsection{Partition Coefficient}

Total petroleum hydrocarbon bio availability in sediment of the rivers solely depends on its distribution between the sediment and the surface water. It lies on the level of total petroleum hydrocarbon in the sediment phase and surface water phase. The spread of the distribution is measured by partition coefficient. The partition coefficient is mathematically represented as

$$
\mathrm{Kd}=\frac{\text { concentration of TPH in Sediment }}{\text { concentration of TPH in water }}
$$

This is done to ascertain which of the phases that total petroleum hydrocarbon prefers.

\subsection{Statistical Analysis}

Data obtained were subjected to one-way analysis of variance (ANOVA) to test if there exist a significant difference between mean values obtained from the different station. Where differences existed, Duncan multiple range test (DMRT) was used to separate the means.

\section{Results and Discussions}

The degree of contamination and pollution of the surface water and sediments by total petroleum hydrocarbons in the Orashi River in sampled stations are shown in Table 1 and 2. The extent to which the river was polluted was a factor of the amount of total petroleum hydrocarbons present per litre of water or per kilogram of sediment. The tables revealed the levels of the different fractional components of total petroleum hydrocarbons present in surface water and sediments of the various samples collected from the river. The mean concentrations of total petroleum hydrocarbons in the surface water and sediments of the river are discussed below.

The level of contamination due to total petroleum hydrocarbons in the surface water of Orashi River in the various stations are shown in Table 1 . The concentration/contamination degree of total petroleum hydrocarbons for the stations are; Station 1; $10.913 \pm 2.2022 \mathrm{ml} / \mathrm{L}$, Station 2; 7.645 $\pm 2.683 \mathrm{ml} / \mathrm{L}$, Station 3; 9.074 $\pm 2.1654 \mathrm{ml} / \mathrm{L}$ and Station $4 ; 12.212 \pm 3.3034 \mathrm{ml} / \mathrm{L}$. The various concentration levels showed that Station $4>1>3>2$. The mean concentration level of total petroleum hydrocarbons for the stations is $9.961 \pm 2.5885 \mathrm{ml} / \mathrm{L}$.

The average level of concentration of total petroleum hydrocarbons recorded in this research work in the Orashi Rivers, in the stations were slightly above or below the national acceptable limit of $10.00 \mathrm{mg} / \mathrm{L}$ in surface and groundwater set by DPR and FEPA [47, 48]. However, it is lower than EUEPA acceptable limit of $300 \mu \mathrm{g} / \mathrm{L}$ in river water [49].

The recorded mean concentration of contamination of total petroleum hydrocarbons in this work was found to be lower than that recorded by Ogeleka, et al. [35] in the Odidi and Egwa riverine areas of Warri Delta State which was $97592 \pm 46$ and $91590 \pm 51 \mathrm{mg} / \mathrm{L}$. The present result obtained is also lower than that reported by Alinnor and Nwachukwu [50], the concentration obtained ranged within $23.6 \pm 4.3 \mathrm{mg} / \mathrm{L}$, while investigating the level of total petroleum hydrocarbons. In the work of Howard, et al. [51], the mean concentration of hydrocarbon was found to be $33076.00 \mu \mathrm{g} / \mathrm{L}$, which is higher than the level obtained in this study. Daniel and Nna [7], which recorded between $9.6820 \pm 0.233-24.85462 \pm 8.058 \mathrm{mg} / \mathrm{L}$ and that of Inyang, et al. [3], which recorded a range of 63.52 to $183 \mu \mathrm{g} / \mathrm{L}$ were all above what was obtained in this work.

However, the observed mean concentration value of total petroleum hydrocarbons recorded in this work were found to be above that recorded by Edori and Kpee [52], on a work carried out in the Taylor Creek, which recorded as low as $2.461 \pm 2.687$ to $10.009 \pm 4.145 \mathrm{ml} / \mathrm{L}$ in the stations. The investigation by Ikpe, et al. [44], of total petroleum hydrocarbons in Ethiope River, Oghara Community revealed that mean concentration was as low as $0,004 \pm 0.003$ and $0,008 \pm 0.008 \mathrm{mg} / \mathrm{L}$ and in Isibor and Freeman [53], total petroleum hydrocarbons concentration recorded was between range of not detected to $3.69 \pm 0.19 \mathrm{mg} / \mathrm{L}$, in a work conducted in Egboko River, which were far lower than that obtained from this work.

In other parts of the world, total petroleum hydrocarbons concentration in surface water have been reported, such include the work of Suratman [54], in the Johor Peninsular, Malaysia which reported a level of 25-2795 $\mathrm{gg} / \mathrm{L}$, also the work of Sammarco, et al. [55] on the Deepwater Horizon Gulf of Mexico which recorded a range of $60,000-260,000 \mu \mathrm{g} / \mathrm{L}$ of total petroleum hydrocarbons, and petroleum hydrocarbons pollution level recorded by Sari and Trihadiningrum [56], in Wonocolo oil field was $211,025.73 \mu \mathrm{g} / \mathrm{L}$ were all higher than that obtained from this work.

The presence of total petroleum hydrocarbons in Orashi River was not uniform, there were clear variation from station to station. This is a clear indication that the source of pollution was anthropogenic $[7,52]$. The flow of the rivers and the pattern of wind direction prevalent in the river must have occasioned the non-availability of the lower fractions of total petroleum hydrocarbons. The lower hydrocarbon components of total petroleum hydrocarbons evaporate with ease from the water surface as a result of high temperature and strong wind and thereby not readily available in the water surface/column to be accounted for Daniel and Nna [7]; Ashiru and Ogundare [57]; Edori and Kpee [52]. There is a noticeable absence or near absence of the higher components of total petroleum hydrocarbons in the surface water which may be that since they are heavier, they might have dropped to the sediments or that the crude oil produced in this area contains little measure of the higher components [52]. 
Table-1. Mean $(\mathrm{X} \pm \mathrm{SD})$ concentrations $(\mathrm{mg} / \mathrm{L})$ of Total Petroleum Hydrocarbons in Surface Water of Orashi River from different Stations.

\begin{tabular}{|c|c|c|c|c|}
\hline \multirow[t]{2}{*}{ Carbon Length } & \multicolumn{4}{|c|}{ Stations } \\
\hline & 1 & 2 & 3 & 4 \\
\hline $\mathrm{C} 8$ & $0.238 \pm 0.016$ & - & $0.789 \pm 0.053$ & - \\
\hline C9 & $0.045 \pm 0.005$ & - & $0.040 \pm 0.002$ & - \\
\hline $\mathrm{C} 10$ & $0.048 \pm 0.005$ & - & $0.017 \pm 0.006$ & - \\
\hline $\mathrm{C} 11$ & $0.918 \pm 0.084$ & - & $0.055 \pm 0.002$ & - \\
\hline $\mathrm{C} 12$ & $0.641 \pm 0.068$ & - & $0.234 \pm 0.051$ & - \\
\hline $\mathrm{C} 13$ & $0.426 \pm 0.007$ & - & $0.197 \pm 0.012$ & - \\
\hline $\mathrm{C} 14$ & $0.216 \pm 0.006$ & - & $0.070 \pm 0.001$ & $3.237 \pm 1.290$ \\
\hline $\mathrm{C} 15$ & $0.616 \pm 0.065$ & - & - & $0.479 \pm 0.019$ \\
\hline $\mathrm{C} 16$ & $0.642 \pm 0.072$ & - & - & $0.789 \pm 0.028$ \\
\hline $\mathrm{C} 17$ & $1.020 \pm 0.610$ & - & $0.493 \pm 0.020$ & $3.124 \pm 1.080$ \\
\hline $\mathrm{C} 18$ & $0.456 \pm 0.026$ & $1.635 \pm 0.640$ & $0.387 \pm 0.010$ & $0.078 \pm 0.005$ \\
\hline C19 & $0.545 \pm 0.029$ & $3.110 \pm 1.280$ & $2.292 \pm 0.710$ & $0.526 \pm 0.020$ \\
\hline $\mathrm{C} 2 \mathrm{O}$ & $1.755 \pm 0.580$ & $0.671 \pm 0.830$ & $0.962 \pm 0.060$ & $0.153 \pm 0.009$ \\
\hline $\mathrm{C} 21$ & - & - & - & - \\
\hline $\mathrm{C} 22$ & $0.113 \pm 0.003$ & - & $0.655 \pm 0.056$ & $2.478 \pm 0.790$ \\
\hline $\mathrm{C} 23$ & - & - & - & - \\
\hline $\mathrm{C} 24$ & $0.344 \pm 0.006$ & - & $1.213 \pm 0.600$ & $0.295 \pm 0.018$ \\
\hline $\mathrm{C} 25$ & - & - & - & - \\
\hline $\mathrm{C} 26$ & $1.222 \pm 0.540$ & $2.229 \pm 0.680$ & $1.067 \pm 0.530$ & $0.183 \pm 0.013$ \\
\hline $\mathrm{C} 27$ & - & - & - & - \\
\hline $\mathrm{C} 28$ & $0.577 \pm 0.030$ & - & - & $0.620 \pm 0.021$ \\
\hline C29 & - & - & - & - \\
\hline C30 & $0.535 \pm 0.028$ & - & $0.603 \pm 0.052$ & $0.170 \pm 0.009$ \\
\hline C31 & - & - & - & - \\
\hline C32 & $0.103 \pm 0.003$ & - & - & $0.034 \pm 0.001$ \\
\hline C33 & - & - & - & - \\
\hline C34 & $0.453 \pm 0.020$ & - & - & $0.046 \pm 0.001$ \\
\hline C35 & \pm & - & - & - \\
\hline C36 & \pm & - & - & - \\
\hline C37 & \pm & - & - & - \\
\hline C38 & \pm & - & - & - \\
\hline C39 & \pm & - & - & - \\
\hline $\mathrm{C} 40$ & \pm & - & - & - \\
\hline
\end{tabular}

The level at which total petroleum hydrocarbons were found in the sediments of Orashi River in the stations were recorded in Table 2. In Table 2, the level at which total petroleum hydrocarbons have contaminated the sediments in the various stations revealed that Station 1;22.3925 $\pm 5,2104 \mathrm{ml} / \mathrm{Kg}$, Station 2; 35.1071 $\pm 9.9652 \mathrm{ml} / \mathrm{Kg}$, Station 3; $50.4431 \pm 15.9916 \mathrm{ml} / \mathrm{Kg}$ and Station 4; $29.3869 \pm 8.041 \mathrm{ml} / \mathrm{Kg}$. The degree of contamination in the various stations showed that Station $3>$ Station $2>$ Station 1 . The average concentration level for the stations is $34.3324 \pm 9.8021 \mathrm{ml} / \mathrm{Kg}$.

The mean value obtained for total petroleum hydrocarbons in the Orashi River for the stations were above the acceptable range given by the Federal Ministry of Environment of $30 \mathrm{mg} / \mathrm{Kg}$ in water [58] and below the Directorate of petroleum Resources acceptable limit of $50 \mathrm{mg} / \mathrm{Kg}$ and far below the $5000 \mathrm{mg} / \mathrm{Kg}$ intervention limit set by DPR [59].

The mean concentration of total petroleum hydrocarbons recorded in this work were below or lower than that obtained in the work of Ogeleka, et al. [35], in Egwa $(215700 \pm 77 \mathrm{mg} / \mathrm{Kg})$ and Odidi $(215730 \pm 81 \mathrm{mg} / \mathrm{Kg})$. The work of Etchie, et al. [60], the result obtained for total petroleum hydrocarbons in sediment and soil ranged between 600 to $2300 \mathrm{mg} / \mathrm{Kg}$, and in Adewuyi, et al. [39], the mean concentration level of total petroleum hydrocarbon recorded was $1602.4 \pm 115.3 \mathrm{mg} / \mathrm{Kg}$ in the Ubeji River, Warri, Delta State, Nigeria, were all above that recorded in this study. Total petroleum hydrocarbon recorded in the sediment of Qua-Iboe River by Inyang, et al. [3], had a mean value of $606.83 \pm 229.48 \mathrm{mg} / \mathrm{Kg}$, and in Ezekwe and Utong [61], the total hydrocarbon recorded in the Oturuba Creek ranged between 1546 to $3997.9 \mathrm{mg} / \mathrm{Kg}$ in the dry season and between 1727.5 to $5118.5 \mathrm{mg} / \mathrm{Kg}$ in the wet season and in Adeniji, et al. [62], from sediment samples in the Bufalo River Estuary, Cape Province, South Africa was of the range of 1259 to $11,000 \mathrm{mg} / \mathrm{Kg}$, were all higher than the result from this work.

However, in the work of Edori. and Marcus [63], in the sediments of Taylor Creek recorded an average value of 18.034 to $23.64 \mathrm{mg} / \mathrm{Kg}$ in the months of study were lower than this work. Also, in Ashiru and Ogundare [57], the concentration of the total petroleum hydrocarbon on the sediments of Ugbo water way recorded as low as $0.131 \mathrm{mg} / \mathrm{Kg}$, which is far lower than that recorded in this work. Other cases found to be lower than this work occur in the Northwest of the Persian Gulf with a total mean value of total petroleum hydrocarbons of $45.94 \mu \mathrm{g} / \mathrm{g}$, and that of Adeniji, et al. [64] in the sediments of Algoa Bay, South Africa with a range of 0.72 to $27.03 \mathrm{mg} / \mathrm{Kg}$.

The pollution level of total petroleum hydrocarbons in the sediments of rivers can be classified into four levels as in Massoud, et al. [65] and Ritchie, et al. [66]. The four levels are (10-15 mg/Kg) as unpolluted, (15-50 $\mathrm{mg} / \mathrm{Kg}$ ) as slightly polluted, $(50-200 \mathrm{mg} / \mathrm{Kg})$ as moderately polluted and (>200 $\mathrm{mg} / \mathrm{Kg}$ ) as heavily polluted. Although the level of contamination in this work averagely sum up within $15-50 \mathrm{mg} / \mathrm{Kg}$, it shows that activities such as crude refining, for self-sustenance prevalent in the area and the inability of the Nigerian government to make room for adequate clean-up has given rise to such pollution as experienced.

Sediment acts as natural sink to absorb the contaminants in the water ecological systems. When significant level of pollution due to contamination of the sediments occur, there is the possibility of loss of species and the biodiversity of the ecological frame are completely affected [67]. This situation affects the food chain of the lower 
(bottom) and upper levels of the ecosystem [68]. The impact of the contamination might have direct toxic effect on the bottom dwelling animals and can also negatively affect humans through consumption of fishes or water from such contaminated rivers. Therefore, there is need for proper sediment quality analysis in order to monitor the river ecological systems [69].

Petroleum hydrocarbons manifest toxic effects even at low concentration range of $10-2-1-5 \mathrm{mg} / \mathrm{dm} 3$ and affects aquatic creatures in their developmental stages [70]. The presence of total petroleum hydrocarbons in sediment bring about changes in the pattern of the naturally ecosystem, by altering the metabolic processes and reducing the species present and in general create instability in the ecosystem [71]. Petroleum hydrocarbons when present in the sediment can hinder and reduce the growth of phytoplanktons. Hydrocarbons when carried into the river, may take a long period before being flushed out of the system. The process involved include, dissolution, evaporation, dispersion, emulsification, biodegradation and sedimentation which finally deposits at the bottom of the river. This give severe impact on the aquatic life, as total petroleum hydrocarbons may be buried in the sediment for years without changes in the level of concentration [72, 73].

Table-2. Mean (X $\pm \mathrm{SD})$ concentrations $(\mathrm{ml} / \mathrm{Kg})$ of Total Petroleum Hydrocarbons in Sediments of Orashi River from

\begin{tabular}{|c|c|c|c|c|}
\hline \multirow[t]{2}{*}{ Carbon Length } & \multicolumn{4}{|c|}{ Stations } \\
\hline & 1 & 2 & 3 & 4 \\
\hline $\mathrm{C} 8$ & - & $1.7032 \pm 0.191$ & $2.7356 \pm 0.920$ & $1.9455 \pm 0.210$ \\
\hline C9 & - & $2.9561 \pm 0.980$ & $0.0400 \pm 0.001$ & $1.7869 \pm 0.193$ \\
\hline $\mathrm{C} 10$ & $1.0795 \pm 0.152$ & $0.6757 \pm 0.059$ & $0.0166 \pm 0.000$ & $4.9589 \pm 2.010$ \\
\hline $\mathrm{C} 11$ & $2.3325 \pm 0.510$ & $1.5760 \pm 0.113$ & $5.0552 \pm 2.210$ & $3.7422 \pm 1.500$ \\
\hline $\mathrm{C} 12$ & $0.3750 \pm 0.053$ & $3.4437 \pm 1.361$ & $0.2337 \pm 0.007$ & $3.3006 \pm 1.350$ \\
\hline $\mathrm{C} 13$ & $2.1475 \pm 0.500$ & $0.8432 \pm 0.691$ & $0.1973 \pm 0.004$ & $2.5837 \pm 0.810$ \\
\hline $\mathrm{C} 14$ & $0.5455 \pm 0.021$ & $3.2802 \pm 1.260$ & $0.9138 \pm 0.087$ & $1.7578 \pm 0.190$ \\
\hline $\mathrm{C} 15$ & $1.4411 \pm 0.170$ & $0.0001 \pm 0.000$ & $4.6373 \pm 2.001$ & $0.0609 \pm 0.001$ \\
\hline $\mathrm{C} 16$ & $0.3565 \pm 0.010$ & - & $5.3259 \pm 2.250$ & - \\
\hline $\mathrm{C} 17$ & $8.7569 \pm 3.310$ & $2.1646 \pm 0.821$ & $1.3141 \pm 0.100$ & $1.5516 \pm 0.112$ \\
\hline $\mathrm{C} 18$ & $0.1246 \pm 0.005$ & $0.0957 \pm 0.001$ & $1.4704 \pm 0.112$ & $1.8201 \pm 0.195$ \\
\hline $\mathrm{C} 19$ & $0.6142 \pm 0.051$ & $1.4701 \pm 0.110$ & $0.9364 \pm 0.093$ & $3.1738 \pm 1.320$ \\
\hline $\mathrm{C} 2 \mathrm{O}$ & $0.2129 \pm 0.005$ & $5.0101 \pm 2.100$ & $1.3730 \pm 0.110$ & $0.7020 \pm 0.061$ \\
\hline $\mathrm{C} 21$ & - & $0.2382 \pm 0.005$ & - & - \\
\hline $\mathrm{C} 22$ & $0.1055 \pm 0.005$ & $0.5597 \pm 0.022$ & $8.3667 \pm 3.291$ & $0.1506 \pm 0.005$ \\
\hline $\mathrm{C} 23$ & - & $1.1883 \pm 0.210$ & - & - \\
\hline $\mathrm{C} 24$ & $0.4722 \pm 0.063$ & $0.6925 \pm 0.056$ & $0.5272 \pm 0.053$ & $0.0695 \pm 0.001$ \\
\hline $\mathrm{C} 25$ & - & $1.3067 \pm 0.191$ & - & - \\
\hline C26 & $0.0164 \pm 0.000$ & $2.1947 \pm 0.834$ & $1.8723 \pm 0.196$ & $0.2165 \pm 0.005$ \\
\hline $\mathrm{C} 27$ & - & $0.5790 \pm 0.026$ & - & - \\
\hline C28 & $0.0742 \pm 0.001$ & $1.5143 \pm 0.120$ & $10.5481 \pm 4.010$ & $0.2233 \pm 0.006$ \\
\hline C29 & - & $0.3011 \pm 0.007$ & - & - \\
\hline C30 & $0.9719 \pm 0.071$ & $0.3011 \pm 0.007$ & $0.7920 \pm 0.071$ & $0.6370 \pm 0.056$ \\
\hline C31 & - & $2.1275 \pm 0.731$ & - & - \\
\hline C32 & $1.7219 \pm 0.182$ & $0.8226 \pm 0.065$ & $1.1392 \pm 0.200$ & $0.2158 \pm 0.005$ \\
\hline C33 & - & - & - & - \\
\hline C34 & $1.0442 \pm 0.101$ & $0.0248 \pm 0.001$ & $1.9929 \pm 0.213$ & $0.4902 \pm 0.010$ \\
\hline C35 & - & $0.0263 \pm 0.001$ & - & - \\
\hline C36 & - & $0.0247 \pm 0.001$ & $0.7754 \pm 0.063$ & - \\
\hline C37 & - & $0.0283 \pm 0.001$ & - & - \\
\hline C38 & - & - & - & - \\
\hline C39 & - & $0.0477 \pm 0.002$ & - & - \\
\hline $\mathrm{C} 40$ & - & - & - & - \\
\hline
\end{tabular}

Table 3 showed the partition coefficient of the Orashi River. The partition coefficient is used to explain the preferred stable phase of petroleum hydrocarbon fractions in a river. Results from Table 3 showed that sediment phase is preferred above the surface water phase, which may be as a result of the hydrophobic nature of water. From Table 3, values that are greater than one indicates preference for sediments while values which are less than one shows that the fraction is water loving. The results indicated that the $\mathrm{C}_{12}$ fraction had values less than one, it therefore means that it prefers the water phase, while other fractions were greater than one showing that they are sediment loving. The $\mathrm{C}_{16}, \mathrm{C}_{18}, \mathrm{C}_{22}, \mathrm{C}_{28}, \mathrm{C}_{30}, \mathrm{C}_{32}$ hydrocarbon components were either more in the water phase or sediment phase. This may be due the pattern of river flow at the sampling station or disturbances occasioned by the operators of illegal oil bunkering and associated businesses within the stations or the possibility of fresh discharge into the river during the sampling period.

The higher contamination experienced in the sediment as compared to the surface water may be due to the hydrophobic nature of total petroleum hydrocarbons. Sediments acts as sink to hydrophobic compounds and this leads to accumulation. The rate at which these compounds decomposes will increase the concentration of the various compounds $[74,75]$. The total petroleum hydrocarbons components due to their hydrophobic nature have affinity for solid particles instead of water [76, 77]. This removes the fractions from the water phase, thereby enhancing the higher concentration of total petroleum hydrocarbons on the sediment phase.

The tendency for total petroleum hydrocarbons to have higher concentration in the sediments as compared to the surface water also comes from the fact that complex fractions / components of the hydrocarbon residue are more in the sediment because they sink and settle down to become part of the sediments [77]. This also assert and confirm to the fact that heavier fractions of crude oil (residue) are solids, and hence they prefer the bottom sediments of the river. Wakeman and Themelis [78], agreed that contaminants that are introduced from land base 
runoffs into surface water are quickly attached by suspended particles and thereby rapidly making the contaminant to settle to the bottom of the river which then increases the concentration. This further proves how the sediment is significant in the role of being a natural sink for the marine environment [33].

Table-3. Partition Coefficient of Total Petroleum Hydrocarbon between Sediment and Water Phases in Orashi River

\begin{tabular}{|c|c|c|c|c|}
\hline \multirow[t]{2}{*}{ Carbon Length } & \multicolumn{4}{|c|}{ Stations } \\
\hline & 1 & 2 & 3 & 4 \\
\hline $\mathrm{C} 8$ & - & - & 3.4672 & - \\
\hline C9 & - & - & 1.0000 & - \\
\hline $\mathrm{C} 10$ & 23.9889 & - & 0.9765 & - \\
\hline C11 & 2.5408 & - & 91.9127 & - \\
\hline $\mathrm{C} 12$ & 0.5850 & - & 0.9987 & - \\
\hline $\mathrm{C} 13$ & 5.0411 & - & 1.0015 & - \\
\hline C14 & 2.5255 & - & 13.0543 & 0.5430 \\
\hline C15 & 2.3394 & - & - & 0.1271 \\
\hline $\mathrm{C} 16$ & 0.5553 & - & - & - \\
\hline $\mathrm{C} 17$ & 8.5852 & - & 2.6655 & 0.4967 \\
\hline $\mathrm{C} 18$ & 0.2732 & 0.0585 & 3.7995 & 23.3346 \\
\hline C19 & 1.1270 & 0.4727 & 0.4086 & 6.0338 \\
\hline $\mathrm{C} 2 \mathrm{O}$ & 0.1213 & 7.4666 & 1.4272 & 4.5882 \\
\hline $\mathrm{C}_{21}$ & - & - & - & - \\
\hline $\mathrm{C} 22$ & 0.9336 & - & 12.7736 & 0.0608 \\
\hline $\mathrm{C} 23$ & - & - & - & - \\
\hline $\mathrm{C} 24$ & 1.3727 & - & 0.4346 & 0.2356 \\
\hline $\mathrm{C} 25$ & - & - & - & - \\
\hline C26 & 0.0134 & 0.9846 & 1.7547 & 1.1831 \\
\hline $\mathrm{C} 27$ & - & - & - & - \\
\hline $\mathrm{C} 28$ & 0.1286 & - & - & 0.3602 \\
\hline C29 & - & - & - & - \\
\hline C30 & 1.8166 & - & 1.3134 & 3.7471 \\
\hline C31 & - & - & - & - \\
\hline C32 & 1.8166 & - & - & 6.3471 \\
\hline C33 & - & - & - & - \\
\hline C34 & 2.3051 & - & - & 10.6565 \\
\hline C35 & - & - & - & - \\
\hline C36 & - & - & - & - \\
\hline C37 & - & - & - & - \\
\hline C38 & - & - & - & - \\
\hline C39 & - & - & - & - \\
\hline $\mathrm{C} 4 \mathrm{O}$ & - & - & - & - \\
\hline
\end{tabular}

\section{Conclusion}

The study indicated that the surface water samples and the sediment samples collected and analyzed from the different stations of Orashi River were affected by total petroleum hydrocarbons contamination due to the activities carried out by man in the area that was under investigation. The results obtained from the stations investigated were slightly above or below the $10 \mathrm{mg} / \mathrm{L}$ approved by DPR in water and below the $50 \mathrm{mg} / \mathrm{Kg}$ allowed by the same body in sediments. The contamination of petroleum hydrocarbons has affected the inhabitants in terms of fishing and farming since it has interfered with their mode of living. The proper estimation and ecological risk assessment should be carried out in the area to ascertain the contamination level of total petroleum hydrocarbons in the river and the possible effect occasioned by the pollution on the inhabitants and possible solutions given in order to mitigate and forestall such occurrence in the future.

\section{References}

[1] G. A. Ekaete, K. O. Ibironke, S. P. Olatunde, and O. P. Olaoye, "Heavy metal pollutions and its associated ecological risks in Lagos Lagoon sediments, South-Western Nigeria," American Chemical Science Journal, vol. 9, pp. 1-13, 2015.

[2] R. J. Naiman and M. G. Turner, "A future perspective on North America's freshwater ecosystems," Ecological Applications, vol. 10, pp. 958-970, 2000.Available at: https://doi.org/10.1890/1051-0761(2000)010[0958:afpona]2.0.co;2.

[3] S. E. Inyang, A. B. Aliyu, and A. O. Oyewale, "Total petroleum hydrocarbon content in surface water and sediment of Qua-Iboe River, Ibeno, Akwa-Ibom State, Nigeria," Journal of Applied Sciences and Environmental Management, vol. 22, pp. 1953-1959, 2018.Available at: https://doi.org/10.4314/jasem.v22i12.14.

[4] O. S. Brraich and S. Jangu, "Evaluation of water quality pollution indices for heavy metal contamination monitoring in the water of Harike Wetland (Ramsar Site), India," International Journal of Scientific and Research Publications, vol. 5, pp. 1-6, 2015.

[5] U. Mendie, The nature of water. The theory and practice of clean water production for domestic and industrial use vol. 1. Lagos: LactoMedals Publishers, 2005.

[6] G. W. Vanloon and S. G. Duffy, The hydrosphere. In: Environmental Chemistry: A Global Perspectives, 2nd ed. New York: Oxford University Press, 2005.

[7] I. E. Daniel and P. J. Nna, "Total petroleum hydrocarbon concentration in surface water of Cross River estuary, Niger Delta Nigeria," Asian Journal of Environment and Ecology, vol. 1, pp. 1-7, 2016.Available at: https://doi.org/10.9734/ajee/2016/31102.

[8] A. C. Chindah, S. A. Braide, and O. C. Sibeudu, "Distribution of hydrocarbons and heavy metals in sediment and crustacean (shrimps - Penaeus notialis) from the Bonny/ the New Calabar River Estuary," Niger Delta, AJEAM-RAGEE, vol. 9, pp. 1-17, 2004.

[9] V. Emongore, E. Kealotswe, S. Sankwasa, and S. Keikanetswe, "Pollution indicators in Gaborone industrial effluents," Journal of Applied Science, vol. 5, pp. 147-150, 2005.

[10] D. Lima, M. M. Santos, A. M. Ferreira, C. Micaelo, and M. A. Reis-Henriques, "The use of the shanny Lipophrys pholis for pollution monitoring: A new sentinel species for the Northwestern European marine ecosystems," Environment international, vol. 34, pp. 94-101, 2008. 
[11] S. M. Sebastián, B. Armstrong, J. A. Córdoba, and C. Stephens, "Exposures and cancer incidence near oil fields in the Amazon basin of Ecuador," Occupational and Environmental Medicine, vol. 58, pp. 517-522, 2001.Available at: https://doi.org/10.1136/oem.58.8.517.

[12] R. B. Jackson, A. Vengosh, T. H. Darrah, N. R. Warner, A. Down, R. G. Poreda, G. Osborn, K. Zhao, D. S. J. Jones, and P. R. Pujado, Handbook of petroleum processing. Berlin, Germany: Springer, 2006.

[13] J. D. Karr, "Increased stray gas abundance in a subset of drinking water wells near Marcellus shale gas extraction," Proceeding of National Academy of Science, USA, vol. 110, pp. 11250-1 1255, 2013.Available at: https://doi.org/10.1073/pnas.1221635110.

[14] M. Moslen and C. Miebaka, "Hydrocarbon contamination of sediments in the Niger Delta Region: A case study of the Azuabie creek, upper reaches of the Bonny Estuary, Nigeria," Journal of Environmental Science, Toxicology and Food Technology, vol. 11, pp. 26-32, 2017.

[15] NRC, Oil in the sea 111; Inputs, fates and effects vol. 265. Washington DC, USA: National Academic Press, 2003.

[16] D. A. Azevedo, C. Y. M. Santos, and F. R. Aqumoneto, "Identification of seasonal variation of atmospheric organic pollutants in Campos Dos Goytacazus, Brazil," Atmospheric Environmental Journal, vol. 36, pp. 2383-2395, 2002.

[17] O. Wokoma, "Levels of total hydrocarbon in water and sediment of a polluted tidal creek, Bonny River, Niger Delta, Nigeria," International Journal of Scientific \& Technology Research, vol. 3, pp. 351-354, 2014.

[18] J. F. N. Abowei, "Survival and growth responses of Tilapia guineensis (Blecker, 1862) fingerlings exposed to various levels of crude oil in the laboratory," MSc Thesis, Department of Applied and Environmental Biology, Rivers State University of Science and Technology, Port Harcourt, 1996.

[19] ATSDR, Toxicological profile for total petroleum hydrocarbon (TPH), US Department of Health and human Services. Washington, USA: Public Health Service, 1999.

[20] A. E. Ite.., T. A. Harry, C. O. Obadimu, E. R. Asuaiko, and I. J. Inimi, "Petroleum hydrocarbons contamination of surface and ground in the Niger Delta Region of Nigeria," Journal of Environment Pollution and Human Health, vol. 6, pp. 51-61, 2018.Available at: https://doi.org/10.12691/jephh-6-2-2.

[21] K. Z. Kponee, A. Chiger, I. I. Kakulu, D. Vorhees, and W. Heiger-Bernays, "Petroleum contaminated water and health symptoms: a cross-sectional pilot study in a rural Nigerian community," Environmental Health, vol. 14, pp. 1-8, 2015.Available at: https://doi.org/10.1186/s12940-015-0073-0.

[22] A. E. Ite and K. J. Semple, Biodegradation of petroleum hydrocarbons in contaminated soils. Microbial Biotechnology: Energy and environment, R. Arora ed. Wallingtord: Oxfordshire CAB International, 2012.

[23] A. E. Ite. and U. J. Ibok, "Gas flaring and venting associated with petroleum exploration and production in the Nigeria's Niger Delta," American Journal of Environmental Protection, vol. 1, pp. 70-77, 2013.Available at: https://doi.org/10.12691/env-1-4-1.

[24] O. H. Yakubu, "Addressing environmental health problems in Ogoniland through implementation of United Nations environment program recommendations: environmental management strategies," Environments, vol. 4, p. 28, 2017.Available at: https://doi.org/10.3390/environments4020028.

[25] O. R. Ogri, "A review of the Nigerian petroleum industry and the associated environmental problems," Environmentalist, vol. 21 , pp. 11-21, 2001.

[26] P. Scheren, A. Ibe, F. Janssen, and A. Lemmens, "Environmental pollution in the Gulf of Guinea-a regional approach," Marine Pollution Bulletin, vol. 44, pp. 633-641, 2002.Available at: https://doi.org/10.1016/s0025-326x(01)00305-8.

[27] P. C. Nwilo and O. T. Badejo, "Oil spill problems and management in the Niger Delta," presented at the International Oil Spill Conference Miami Florida, USA, 2000.

[28] C. Okoye and L. Okunrobo, "Impact of oil spill on land and water and its health implications in odu-gboro community, sagamu, ogun state, nigeria," World Journal of Environmental Engineering Science and Technology, vol. 1, pp. 1-2 1, 2014.

[29] A. A. Adeniyi and J. A. Afolabi, "Determination of total petroleum hydrocarbons and heavy metals in soils within the vicinity of facilities handling refined petroleum products in Lagos metropolis," Environment International, vol. 28, pp. 79-82, 2002.

[30] L. C. Osuji and S. O. Adesiyan, "The Isiokpo oil-pipeline leakage: Total organic carbon/organic matter contents of affected soils," Chemistry \& Biodiversity, vol. 2, pp. 1079-1085, 2005.Available at: https://doi.org/10.1002/cbdv.200590077.

[31] S. Olobaniyi and S. Efe, "Comparative assessment of rainwater and groundwater quality in an oil producing area of Nigeria: Environmental and health implications," Journal of Environmental Health Research, vol. 6, pp. 111-118, 2007.

[32] T. Monazami, GH, H. Rosli, A. Sulaiman, B. T. Sany, A. Salleh, F. Owfi, A. Savari, R. K. Jazani, and Z. M. Tehrani, "Petroleum hydrocarbon assessment in the wastewaters of petrochemical special economic zone and sediment benchmark calculation of the coastal area-northwest of the Persian Gulf," Iranian Journal of Fisheries Sciences, vol. 13, pp. 119-134, 2014.

[33] F. D. Udoh and M. Akpan, "Effect of oil spillage on Alakiri community in Okrika local government area of Rivers State, Nigeria," Journal of Industrial Pollution Control, vol. 26, pp. 139-143, 2010.

[34] M. C. Blackburn, A. S. Mazzacano, and C. Fallon, "Oil in our oceans: A review of impacts of oil spills on marine invertebrates," ed Portland, Oregon, USA: Matthew Shepherd, Printing, 2014, p. 152.

[35] D. F. Ogeleka, O. Edjere, A. Nwudu, and F. E. Okieimen, "Ecological effects of oil spill on pelagic and bottom dwelling organisms in the riverine areas of Odidi and Egwa in Warri, Delta State," Journal of Ecology and the Natural Environment, vol. 8, pp. 201-211, 2016.Available at: https://doi.org/10.5897/jene2016.0593.

[36] Y. K. Kharaka, J. S. Hanor, d. H. heinrch, and K. T. Karh, "Deep fluids in the continents: I. Sedimentary basins, Treatise on Geochemistry," ed Oxford, UK: Pergamon, 2007, pp. 1-48.

[37] F. O. Arimoro, J. E. Uku, and N. O. Odume, "Effects of petroleum pollution in Niger Delta wetlands: Interplay between the social and ecological systems. Recent advances in environmental science from the Euro-Mediterranean and surrounding regions," in Proceedings of Euro-Mediterranean Conference for Environmental Integration (EMCEI-1), Tunisia 2017, Kallel, A., Ksibi, M., Ben Dhia, H. and Khelifi, N. eds Cham. Springer International Publishing, 2018, pp. 151-152.

[38] O. U. Eka and I. R. Udotong, A case study of effects of incessant oil spills from Mobil Producing Nigeria unlimited on human health in Akwa-Ibom State. In: Environmental Pollution Management in the Tropics vol. 14: Edited by Adinna, E.N, 2003.

[39] G. O. Adewuyi, O. T. Etchie, and O. T. Ademoyegun, "Determination of total petroleum hydrocarbon and heavy metals in surface water and sediment of Ubeji, Warri, Nigeria," Bioremediation, Biodiversity and Bioavailability, vol. 5, pp. 46-51, 2011.

[40] W. Guo, M. He, Z. Yang, C. Lin, and X. Quan, "Aliphatic and polycyclic aromatic hydrocarbons in the Xihe River, an urban river in China's Shenyang City: Distribution and risk assessment," Journal of Hazardous Materials, vol. 186, pp. 1193-1199, 2011.Available at: https://doi.org/10.1016/j.jhazmat.2010.11.122.

[41] A. Hajisamoh, "Pollution levels of 16 priority PAHs in the major rivers of Southern Thailand," Research and Revierws: Journal of Chemistry, vol. 2, pp. 7-11, 2013.

[42] S. Uzoekwe and F. Oghosanine, "The effect of refinery and petrochemical effluent on water quality of Ubeji Creek Warri, Southern Nigeria," Ethiopian Journal of Environmental Studies and Management, vol. 4, pp. 107-116, 2011.Available at: https://doi.org/10.4314/ejesm.v4i2.12.

[43] W. Ashraj, "Accumulation of heavy metals in kidney and heart tissues of Epinephelus microdon fish from the Arabian Gulf," Environmental Monitoring and Assessment, vol. 101, pp. 311-316, 2005.Available at: https://doi.org/10.1007/s10661-005-0298-4.

[44] E. E. Ikpe, A. E. Akpakpan, E. W. Nsi, and A. N. Ekanem, "Determination of the level of petroleum hydrocarbon in water, fishes and plants from part of River Ethiope, Ogara in Delta State, Nigeria," International Journal for Research in Applied Chemistry, vol. 2, pp. 1-10, 2016.

[45] LAWI, For the determination of total petroleum hydrocarbon in soil /sediment/sludge in Gas Chromatography vol. 9. Lagos, Nigeria: Fugro (Nig). Ltd, 2011.

[46] J. E. Cortes, A. Suspes, S. Roa, C. González, and H. E. Castro, "Total petroleum hydrocarbons by Gas Chromatography in Colombian waters and soils," American Journal of Environmental Science, vol. 8, pp. 396-402, 2012.Available at: https://doi.org/10.3844/ajessp.2012.396.402.

[47] FEPA, "Guidelines and standards for environmental pollution control in Nigeria," ed Lagos, Nigeria: FEPA, 2003, p. 238.

[48] DPR, Environmental guidelines and standards for the petroleum industry in Nigeria (EGASPIN). Lagos, Nigeria: Universal Press, 2011. 
[49] EUEPA, "Framework for the use of Rapid Measurement Techniques (RMT) in the risk management of sediment and water contamination," UK, Directorate-General for Environment European Commission 1049 Bruxelles/Brussel Belgium, 2009.

[50] I. J. Alinnor and M. A. Nwachukwu, "Determination of total petroleum hydrocarbon in soil and groundwater samples in some communities in Rivers State, Nigeria," Journal of Environmental Chemistry and Ecotoxicology, vol. 5, pp. 292-297, 2013.

[51] I. C. Howard, U. U. Gabriel, and M. Horsfall, "Evaluation of total hydrocarbon levels in some aquatic media in an oil polluted mangrove wetland in the Niger Delta," Applied Ecology and Environmental Research, vol. 7, pp. 111-120, 2009.Available at: https://doi.org/10.15666/aeer/0702_111120.

[52] E. S. Edori and F. Kpee, "Total petroleum hydrocarbon concentration in surface water from Taylor Creek, Rivers State, Nigeria," Chemistry Research Journal, vol. 4, pp. 1-8, 2019.

[53] P. O. Isibor and O. E. Freeman, "Evaluation of some heavy metals and total petroleum hydrocarbon in water and palaemonid shrimps (Macrobrachium vollenhoenii) of Egboko River, Warri, Delta State, Nigeria," 2016.

[54] S. Suratman, "Distribution of total petrogenic hydrocarbon in Dungun River basin, Malaysia," Oriental Journal of Chemistry, vol. 29, pp. 77-80, 2013.Available at: https://doi.org/10.13005/ojc/290112.

[55] P. W. Sammarco, S. R. Kolian, R. A. Warby, J. L. Bouldin, W. A. Subra, and S. A. Porter, "Distribution and concentrations of petroleum hydrocarbons associated with the BP/Deepwater Horizon Oil Spill, Gulf of Mexico," Marine Pollution Bulletin, vol. 73, pp. 129-143, 2013.Available at: https://doi.org/10.1016/j.marpolbul.2013.05.029.

[56] G. L. Sari and Y. Trihadiningrum, "Petroleum hydrocarbon pollution in soil and surface water by public oil fields in Wonocolo Sub-district, Indonesia," Journal of Ecological Engineering, vol. 19, pp. 184-193, 2018.Available at: https://doi.org/10.12911/22998993/82800.

[57] O. R. Ashiru and M. O. Ogundare, "An assessment of total petroleum hydrocarbon and trace metal concentration in the sediment of Ugbo Water way South Western Nigeria," African Journal of Environmental Science and Technology, vol. 13, pp. 13-21, 2019.Available at: https://doi.org/10.5897/ajest2018.2578.

[58] FME, "Guidelines and standards for environmental pollution in Nigeria," ed Lagos, Nigeria: Federal Environmental Protection Agency, 1991, p. 238.

[59] DPR, "EGASPIN soil/sediment target and intervention values for Mineral oil (or TPH),॥ in Environmental Guidelines and Standards for The Petroleum Industry in Nigeria." vol. 2, ed Lagos, Nigeria: Department of Petroleum Resources (DPR), 2002, pp. $1-415$.

[60] T. O. Etchie, A. T. Etchie, and G. O. Adewuyi, "Source identification of chemical contaminants in a rural settlement," Research Journal of Environmental Sciences, vol. 5, pp. 730-740, 2011 .Available at: https://doi.org/10.3923/rjes.2011.730.740.

[61] C. I. Ezekwe and I. C. Utong, "Hydrocarbon pollution and potential risk of heavy metals in the sediments of Oturuba Creek, Niger Delta, Nigeria," Journal of Environmental Geography, vol. 10, pp. 1-10, 2017.Available at: https://doi.org/10.1515/jengeo-20170001 .

[62] A. O. Adeniji, O. O. Okoh, and A. I. Okoh, "Petroleum hydrocarbon profiles of water and sediment of Algoa Bay, Eastern Cape, South Africa," International Journal of Environmental Research and Public Health, vol. 14, p. 1263, 2017.Available at: https://doi.org/10.3390/ijerph14101263.

[63] E. S. Edori. and A. C. Marcus, "Total petroleum hydrocarbons content of Taylor Creek, Rivers State, Niger Delta Nigeria," International Journal of Advanced Research in Chemical Science, vol. 6, pp. 16-23, 2019.Available at: https://doi.org/10.20431/23490403.0612003.

[64] A. O. Adeniji, O. O. Okoh, and A. I. Okoh, "Petroleum hydrocarbon fingerprints of water and sediment samples of Buffalo River Estuary in the Eastern Cape Province, South Africa," Journal of Analytical Methods in Chemistry, vol. 25, pp. 1-13, 2017.Available at: https://doi.org/10.1155/2017/2629365.

[65] M. Massoud, F. Al-Abdali, A. Al-Ghadban, and M. Al-Sarawi, "Bottom sediments of the Arabian Gulf-II. TPH and TOC contents as indicators of oil pollution and implications for the effect and fate of the Kuwait oil slick," Environmental Pollution, vol. 93, pp. 271-284, 1996.Available at: https://doi.org/10.1016/s0269-7491(96)00042-5.

[66] G. D. Ritchie, K. R. Still, W. K. Alexander, A. F. Nordholm, C. L. Wilson, J. Rossi Iii, and D. R. Mattie, "A review of the neurotoxicity risk of selected hydrocarbon fuels," Journal of Toxicology and Environmental Health Part B: Critical Revieres, vol. 4, pp. 223-312, 2001.Available at: https://doi.org/10.1080/10937400118874.

[67] D. L. Markovic, "Untreated municipal waste discharge in Victoria Bight, British Columbia, Canada: An investigation of sediment metal contamination and implications for sustainable development," M. Sc. Thesis. Sciences, Technology and Environment Division Royal Roads University, Canada, 2003.

[68] G. A. Burton Jr, "Sediment quality criteria in use around the world," Limnology, vol. 3, pp. 65-76, 2002.

[69] USEPA, "Sediment classification methods compendium," Sediment Oversight Technical Committee Office of Water (WH-556). EPA 823-R-92-006, EPA Work Assignment Manager, Washington, D. C, USA, pp 2301992.

[70] V. Kurylenko and O. Izosimova, "Study of the impact of petroleum hydrocarbons on Sea organisms," Journal of Ecological Engineering, vol. 17, pp. 26-29, 2016.

[71] T. F. Kurochkina, "Environmental safety during exploration in the North Caspian," Natural Nauki, vol. 4, pp. $235-237,2008$.

[72] S. R. Wild and K. C. Jones, "Polynuclear aromatic hydrocarbons in the United Kingdom environment: A preliminary source inventory and budget," Environmental Pollution, vol. 88, pp. 91-108, 1995.Available at: https://doi.org/10.1016/0269$7491(95) 91052-\mathrm{m}$

[73] C. M. Reddy, T. L. Eglinton, A. Honnshell, W. H. K., L. Xu, R. B. Gaines, and G. S. Frysinger, "The West falmouth oil spill after thirty years: The persistence of petroleum hydrocarbons in Marsh sediments," Environmental Science and Technology, vol. 36, pp. 754-4, 2002.Available at: https://doi.org/10.1021/es020656n.

[74] Environment Canada, "Toxic chemicals in Atlantic Canada-polyaromatic hydrocarbons (PAH)," ed Ottewa: Government of Canada, 2001, p. 107.

[75] P. B. Ging, P. C. Van Metre, and E. Callender, "Bottom sediments of Lorence Creek Lake, San Antonio Texas, USA, Reflect contaminant trends in an urbanizing Watershed," pp. 1-28, 2001.

[76] G. Kiss, Z. Vargas-Puchony, A. Gelembcser, Z. Krivacsy, A. Molnar, and J. Hlavay, "Survey of concentration of polycyclic aromatic hydrocarbons in Lake Balaton by HPLC with fluorescence detection," Chromatography, vol. 48, pp. 149-153, 1998.Available at: https://doi.org/10.1007/BF02467532.

[77] I. Ololade, L. Lajide, and I. Amoo, "Spatial trends of petroleum hydrocarbons in water and sediments," Open Chemistry, vol. 7, pp. 83-89, 2009.Available at: https://doi.org/10.2478/s1 1532-008-0086-4.

[78] T. H. Wakeman and N. J. Themelis, "A basin-wide approach to dredged material management in New York/New Jersey Harbor," Journal of Hazardous Materials, vol. 85, pp. 1-13, 2001.Available at: https://doi.org/10.1016/s0304-3894(01)00218-7. 